\title{
The effects of state-level Earned Income Tax Credits on suicides
}

\author{
Otto Lenhart ${ }^{\text {a }}$ \\ ${ }^{\text {a }}$ University of Strathclyde \\ Department of Economics \\ Duncan Wing, Strathclyde Business School \\ 199 Cathedral Street, Scotland, UK \\ Email: ottolenhart@gmail.com \\ Phone: +44-7503-909603 \\ ORCID ID: 0000-0003-0949-4820
}

August 6, 2019

\begin{abstract}
This study examines the relationship between state-level Earned Income Tax Credit (EITC) laws in the U.S. on suicides. Following findings in previous work showing that the EITC is associated with lower depression rates and reduced number of risky biomarkers, I estimate the effects of state EITC generosity on suicide rates. Using data for the years 1996 to 2016, a period with 74 state-level EITC policy changes, I find that introducing a high state EITC rate reduces suicide rates for adults aged 25 or above by 3.91 percent. The results are consistent across four different measures of EITC generosity.
\end{abstract}

Keywords: Earned Income Tax Credit; Suicide; Mental health

JEL Codes: I10, I14, I38, J38 


\section{1) INTRODUCTION}

Between 1996 and 2016, the annual number of suicides in the U.S. increased from 30,903 to 44,965 , which corresponds to a suicide every 11.7 minutes rather than every 17.0 minutes. While there is no consensus on the determinants for this rise in suicides, crosscountry evidence shows that suicide rates are related to labor market participation and unemployment rates (Milner et al., 2012), suggesting that one in five suicides worldwide is associated to unemployment (Nordt et al., 2015). Another likely explanation for the increases in suicide rates in the U.S. is the growing prevalence of mental health issues and depression (Twenge et al., 2019).

The Earned Income Tax Credit (EITC) has been shown to improve employment and overall well-being of individuals in the U.S. The federal EITC, a tax credit for low-income working families introduced in 1975 to supplement incomes and reduce tax burdens, has been praised as the largest and most effective anti-poverty program in the United States (Hoynes, 2016; Marr et al., 2015). In 1988, 13 years after the introduction of the federal EITC, U.S. states began introducing state-level credits on top of the federal rate. In 2016, 26 states plus Washington DC had a state EITC in place, with the generosity of the credits varying from 3.5 percent of the federal rate (Louisiana) to 85 percent of the federal rate (California). This study examines the role of state-level EITC laws in reducing suicide rates for adults aged 25 or above.

Case and Deaton (2015) show that overall increases in suicides between 1999 and 2013 were driven by individuals with at most a High School degree, a group that is most likely to be eligible for EITC benefits. The main mechanisms underlying the relationship between EITC laws and suicides are employment and poverty. Prior work has established that the EITC is successful in moving households above the poverty threshold by providing 
incentives for employment (Scholz 1994; Neumark and Wascher 2000; Meyer 2010; Short 2014; Hoynes and Patel 2018). Short (2014) finds that the program lifted 4.7 million children out of poverty in 2013, more than any other program. Suggestive of employment being a likely mechanism through which EITC laws affect suicide rates, Kposowa (2001) finds that there is a strong and persistent relationship between unemployment and suicide rates.

Other work on the EITC has shown that the program reduces depression and increases happiness and self-esteem (Boyd-Swan et al., 2016), and improves physical and mental health outcomes (Averett and Wang, 2013; Evans and Garthwaite, 2014; Boyd-Swan et al., 2016; Lenhart, 2019), birth outcomes (Hoynes et al., 2015; Hamad and Rehkopf, 2015; Markowitz et al., 2017) and health insurance coverage (Baughman, 2005; Hoynes et al., 2015; Baughman and Duchovny, 2016; Lenhart, 2019). It appears likely that expansions of the program affects the levels of financial security and stress for low-income families and that a combination of these factors can explain a potential association between EITC benefits and suicides.

Using data for the years 1996 to 2016, a period with 74 changes in state-level EITC rates, this study provides evidence that EITC generosity is strongly associated with reductions in the number of suicides in a state. I find that introducing a high EITC rate (at least 10 percent of the federal rate) reduces the state suicide rate by 3.91 percent, while a 10percentage point increase in the state EITC rate reduces suicides rates by 3.89 percent.

\section{2) DATA AND METHODS}

The study uses state-level suicide data from annual reports on deaths in the U.S., which are provided by the National Vital Statistics System. I use age-adjusted state-level rates of suicide per 100,000 capturing suicides for individuals aged 25 and over. Figure 1 presents changes in state suicide rates among individuals in this age range over the sample 
period. Besides showing that suicide rates have consistently increased in the U.S., especially since 2005, Figure 1 also shows that rates are substantially lower in states with state EITC laws compared to states without state EITC policies.

Information on state EITC rates is obtained from annual reports by the Internal Revenue Service (IRS). Table 1 provides an overview of the number of annual changes to state EITC benefits between 1996 and 2016. For the baseline analysis, I divide states into three groups: 1) states with no EITC (reference category); 2) states with EITC benefits of less than $10 \%$; 3) states with EITC benefits of at least $10 \%$. The cutoff of $10 \%$ of the federal credit is used because it is the median value of EITC benefits over the sample period and can be considered a measure of low generosity versus high generosity. ${ }^{1}$ Table 2 provides an overview of nominal dollar amounts associated with this 10 percent cutoff. The average annual benefit for a 10 percent state EITC between 1996 and 2016 for families with one child, two children, and 3 or more children are $\$ 276.67, \$ 458.05$, and $\$ 472.00$, respectively. In addition to state EITC rates, I also collect information on whether the credit is refundable because refunds can provide substantial additional income to recipients that is not reflected in the EITC value alone (Markowitz et al., 2017).

Using the 74 state-level EITC changes during the sample period, I estimate multistage, multi-year difference-in-differences models to evaluate the effects of state EITCs on suicide rates. The main equation of interest is:

$$
\text { Suicide }_{\mathrm{st}}=\beta_{0}+\beta_{1} \text { EITC }_{\mathrm{st}}+\beta_{2} \mathrm{X}_{\mathrm{st}}+\lambda_{1} \text { Year }_{\mathrm{t}}+\lambda_{2} \text { State }_{\mathrm{s}}+\varepsilon_{\mathrm{st}},
$$

where Suicide $_{\text {st }}$ is the log of the age-adjusted suicide rate (per 100,000) in state s and year t, while EITC $_{\text {st }}$ are several measures of EITC generosity in the state at the relevant time. $\mathrm{X}_{\mathrm{st}}$

\footnotetext{
${ }^{1}$ Due to its unique structure of the EITC law, which does not match the measurement model used for all other states, Maryland is excluded from the analysis (Markowitz et al., 2017).
} 
represents a set of controls accounting for potential confounding between suicide rates and EITC benefits. These controls include state unemployment rates, state-level real GDP, and the share of the state population below the age of 65 without any insurance coverage. ${ }^{2}$ Additionally, the analysis includes both year and state fixed effects. Standard errors in all models are adjusted for within-state serial correlation by clustering at the state level. ${ }^{3}$

While the main analysis evaluates the effects of more generous EITC laws using difference-in-differences models for which states without EITC laws form the comparison group, I also estimate two additional fixed effect OLS models using alternative measures of EITC generosity to test whether the association is robust to different EITC measures. First, I narrow the sample to states that have state EITC laws in place and measure the effect of a 10percentage point increase in EITC rates on suicides, which allows me to estimate the average effect of all within state changes to EITC benefits. Second, I estimate the effect of withinstate switches from no EITC to having a state EITC, independent of the size of the credit. This model can provide evidence for average effects of state EITC implementations on suicide rates.

A limitation of the analysis is that it uses aggregate state suicide rates, rather than information on suicide rates among subgroups of the population that are most likely affected by EITC law changes. While previous work has shown that EITC take-up rates are around 80 to 87 percent (Internal Revenue Service, 2002; Scholz, 1994), I do not have information whether all eligible state residents applied for or received state EITC benefits. Furthermore, I

\footnotetext{
${ }^{2}$ State unemployment data is collected from the Bureau of Labor Statistics, real GDP data comes from the Bureau of Economic Analysis, and insurance data is obtained Current Population Survey. If EITC encourages entry into the labor market, unemployment rates would be unaffected. Thus, I control for annual state poverty rates in additional models. The findings remain almost unchanged. Furthermore, controlling for uninsurance rate might not capture changes in quality or coverage of mental health services if EITC eligible individuals were previously covered by Medicaid. In additional specification, I control for Medicaid state eligibility thresholds. Again, the results remain unchanged.

${ }^{3}$ I estimate OLS models to measure the effects of EITC generosity on suicide rates.
} 
do not know the share of the population at risk of suicide that receives EITC payments. Thus, equation (1) is estimating intent-to-treat effects. Evidence by Case and Deaton (2015) shows that recent increases in U.S. mortality rates was largely driven by increases in suicides among middle-age men with at most a High School degree, a group likely to be eligible for the EITC. ${ }^{4}$ Given that my study uses aggregate suicide rates, it seems likely that the estimates provide a lower-bound for the effect of EITC laws on suicide rates. ${ }^{5}$

\section{3) RESULTS}

Table 3 provides the main estimates of the analysis. Using three categories of generosity, Panel A shows that, compared to states with no EITC, introducing a rate of at least $10 \%$ is associated with reductions in annual age-adjusted suicide rates by 4.05 and 3.91 percent in the baseline model and in full specification, respectively (both $\mathrm{p}<0.05$ ). While implementing a low EITC rate also reduces the number of suicides, the estimate is smaller and only slightly significant in the full specification. ${ }^{6}$ The results in Panel B, which additionally accounts for whether state EITCs are refundable, indicate that having refundable credits can further decrease suicide rates in states with generous rates, while refundability does not appear to make a difference in low-EITC states.

\footnotetext{
${ }^{4}$ Appendix Table A1 confirms that both male and female suicide rates increased during the study period. Appendix Figures A1 and A2 show that both male and female suicide rates (age 25 or above) are substantially higher for individuals with at most a High School degree. Both figures indicate that individuals with less than a high school degree have lower suicide rates than those with a high school degree. As suggested by Phillips and Hempstead (2017), the non-linearity in the U.S. relationship could partly be explained by the fact that the population with no high school degree includes a disproportionate share of foreign-born residents, for whom low educational attainment is less of a marker. In line with this, Phillips and Hempstead (2017) show that suicide rates for native-born men without a high school degree were larger than for those with completed high school education.

${ }^{5}$ To test for the presence of parallel trends between the groups, Appendix Figure A3 shows descriptive suicide statistics for states without any state EITC and the eight states that increased their state EITC benefits in 2008. The graph shows that trends in suicides were similar before 2008, whereas a widening of the gap is noticeable a year after the policy changes were implemented.

${ }^{6}$ Showing trends in suicide rates for all three groups over time, Appendix Figure A4 shows that states with high EITCs have by far the fewest suicides throughout the sample period.
} 
While Panels A and B use a 10\% cutoff to evaluate within-state changes in the generosity of EITC benefits, the estimates in Panel C show the effects of any within-state EITC increase on suicide rates. The results, which are scaled to represent the effects of a 10percentage point increase in EITC benefits, are in line with the DD estimates. A 10percentgae point increase in state EITC reduces suicide rates by 3.89 percent $(p<0.05)$. Finally, Panel D measures the effect of within-state changes from having no EITC rate to having a credit rate, independent of its generosity. In line with the other estimates presented in Table 3, I find that introducing a state EITC law decreases suicide rates by 3.12 percent $(\mathrm{p}<0.05)$.

\section{4) DISCUSSION}

This study finds that introducing a generous state EITC rate is associated with a 3.91 percent decline in age-adjusted suicide rates. Given the number of suicides during the sample period, such a decline would have corresponded to around 1,380 fewer suicides each year. The estimated association is robust to several measures of EITC generosity and to the inclusion of potentially confounding factors, such as state unemployment and uninsurance rates. The results are in line with previous evidence showing an inverse relationship between suicides and labor market policies, such as minimum wages (Gertner et al., 2019), unemployment protection/benefits (Norström and Grönqvist, 2015; Cylus et al., 2014), and labor market participation programs (Stuckler et al., 2009).

The results of this study also add to previous work on health-related effects of EITC benefits. While the main likely channel underlying the relationship are reductions in poverty by providing incentives for seeking employment to low-income households, other studies have shown that several other factors might also explain health improvements following more generous EITC laws. Researchers have shown that the program reduces depression and 
increases happiness and self-esteem (Boyd-Swan et al., 2016), while reducing the number of risky biomarkers (Evans and Garthwaite, 2014), and reducing female smoking rates during and after pregnancies (Averett and Wang, 2013; Hoynes et al., 2015) among individuals likely affected by EITC expansions. By providing evidence that higher EITCs are associated with reductions in suicides, this study confirms that the program can significantly reduce stress levels and improve mental well-being.

Appendix Table A2 furthermore provides suggestive evidence that EITC generosity is associated with the prevalence of mental illness and access to mental health care, which is in line with evidence showing an association between EITC laws and health insurance coverage (Baughman, 2005; Hoynes et al., 2015; Baughman and Duchovny, 2016; Lenhart, 2019). While the prevalence of both mental health issues and suicides has increased substantially in the U.S. over the last two decades, the findings of this study suggest that income assistance programs like the EITC can improve both outcomes and thus improve the well-being of society.

\section{REFERENCES}

Averett, S., Wang, Y. (2013). The effects of Earned Income Tax Credit payment expansion on maternal smoking. Health Economics, 22: 1344-1359.

Baughman, R. A., Duchovny, N. (2016). State Earned Income Tax Credits and the Production of Child health: Insurance Coverage, Utilization, and Health Status. National Tax Journal 69(1): 103-132.

Baughman, R. A. (2005). Evaluating the Impact of the Earned Income Tax Credit on Health Insurance Coverage. National Tax Journal 58(4): 665-684.

Boyd-Swan, C., Herbst, C. M., Ifcher, J., Zarghamee, H. (2016). The Earned Income Tax Credit, mental health, and happiness. Journal of Economic Behavior \& Organization, 126: $18-38$.

Case, A., Deaton, A. (2015). Rising morbidity and mortality in midlife among white nonHispanic Americans in the 21st century. Proceedings of the National Academy of Sciences, 112 (49): 15078-15083. 
Cylus, J., Glymour, M. M., Avendano, M. (2014). Do generous unemployment benfit programs reduce suicide rates? A state fixed-effect analysis covering 1968-2008. American Journal of Epidemiology, 180 (1): 45-52.

Evans, W. N., Garthwaite, C. L. (2014), Giving mom a break: The impact of higher EITC payments on maternal health. American Economic Journal: Economic Policy, 6: 258290.

Florence, C., Simon, T., Haegerich, T., Luo, F., Zhou, C. (2015). Estimated lifetime medical and work-loss costs of fatal injuries-United States, 2013. MMWR Morb Mortal Wkly Rep., 64 (38): 1074-1077.

Gertner, A. K., Rotter, J. S., Shafer, P. R. (2019). Association between state minimum wages and suicide rates in the U.S. American Journal of Preventive Medicine, 56 (5): 648654.

Hamad, R., Rehkopf, D. H. (2016). Poverty and child development: A longitudinal study of the impact of the Earned Income Tax Credit. American Journal of Epidemiology, 183(9): 775-784.

Hoynes, H. W., Patel, A. J. (2018). Effective Policy for Reducing Poverty and Inequality? The Earned Income Tax Credit and the Distribution of Income. Journal of Human Resources 53: 859-890.

Hoynes, H. (2016). Policy Brief. Institute for Research on Labor and Employment, University of California Berkley. The Earned Income Tax Credit: A key policy to support families facing wage stagnation.

Hoynes, H. W., Miller, D. L., Simon, D. (2015). Income, the Earned Income Tax Credit, and infant health. American Economic Journal: Economic Policy, 7 (1): 172-211.

Kposowa, A. J. (2001). Unemployment and Suicide: A Cohort Analysis of Social Factors Predicting Suicide in the US National Longitudinal Mortality Study. Psychological Medicine, 31: 127-138.

Lenhart, O. (2019). The Effects of Income on Health: New Evidences from the Earned Income Tax Credit. Review of Economics of the Household, 17(2): 377-410.

Markowitz, S., Komro, K., Livingston, M., Lenhart, O., Wagenaar, A. (2017). Effects of state-level Earned Income Tax Credit laws in the U.S. on maternal health behaviors and infant health outcomes. Social Science \& Medicine, 194: 67-75.

Marr, C., Huang, C.-C., Sherman, A., DeBot, B. (2015). EITC and Child Tax Credit promote work, reduce poverty, and support children's development, research finds. Center on Budget and Policy Priorities.

Meyer, B. D. (2010). The Effects of the Earned Income Tax Credit and Recent Reforms. Tax Policy and the Economy 24: 153-180.

Milner, A. McClure, R., De Leo, D. (2012). Socio-Economic Determinants of Suicide: An Ecological Analysis of 35 Countries. Social Psychiatry and Psychiatric Epidemiology 47(1): 19-27.

Neumark, D., Wascher, W. (2001). Using the EITC to Help Poor Families: New Evidence and a Comparison with the Minimum Wage. National Tax Journal 54(2): 281-317. 
Nordt, C., Warnke, I., Seifritz, E., Kawohl, W. (2015). Modelling Suicide and Unemployment: A Longitudinal Analysis Covering 63 Countries, 2000-11. The Lancet 2(3): P239-245.

Norström, T., Grönqvist, H. (2015). The Great Recession, unemployment and suicide. $J$ Epidemiol Community Health, 69: 110-116.

Phillips, J. A., Hempstead, K. (2017). Differences in U.S> Suicide Rates by Educational Attainment, 2000-2014. American Journal of Preventive Medicine, 53(4): e123-e130.

Scholz, J. K. (1994). The Earned Income Tax Credit: Participation, Compliance, and AntiPoverty Effectiveness. National Tax Journal 47(1): 59-81.

Short, K. (2014). The Research Supplemental Poverty Measure: 2013. Current Population Reports P60-251. U.S. Census Bureau.

Stuckler, D., Basu, S., Suhrcke, M., Coutts, A., McKee, M. (2009). The public health effect of economic crises and alternative policy responses in Europe: an empirical analysis. Lancet, 374 (9686): 315-323.

Twnge, J. M., Bell Cooper, A., Joiner, T. E., Duffy, M. E., Binau, S. G. (2019). Age, Period, and Cohort Trends in Mood Disorder Indicators and Suicide-Related Outcomes in a Nationally Representative Dataset, 2005-2017. Journal of Abnormal Psychology 128(3): 195-199. 
Figure 1: Changes in Suicides over Time, Age 25 or above

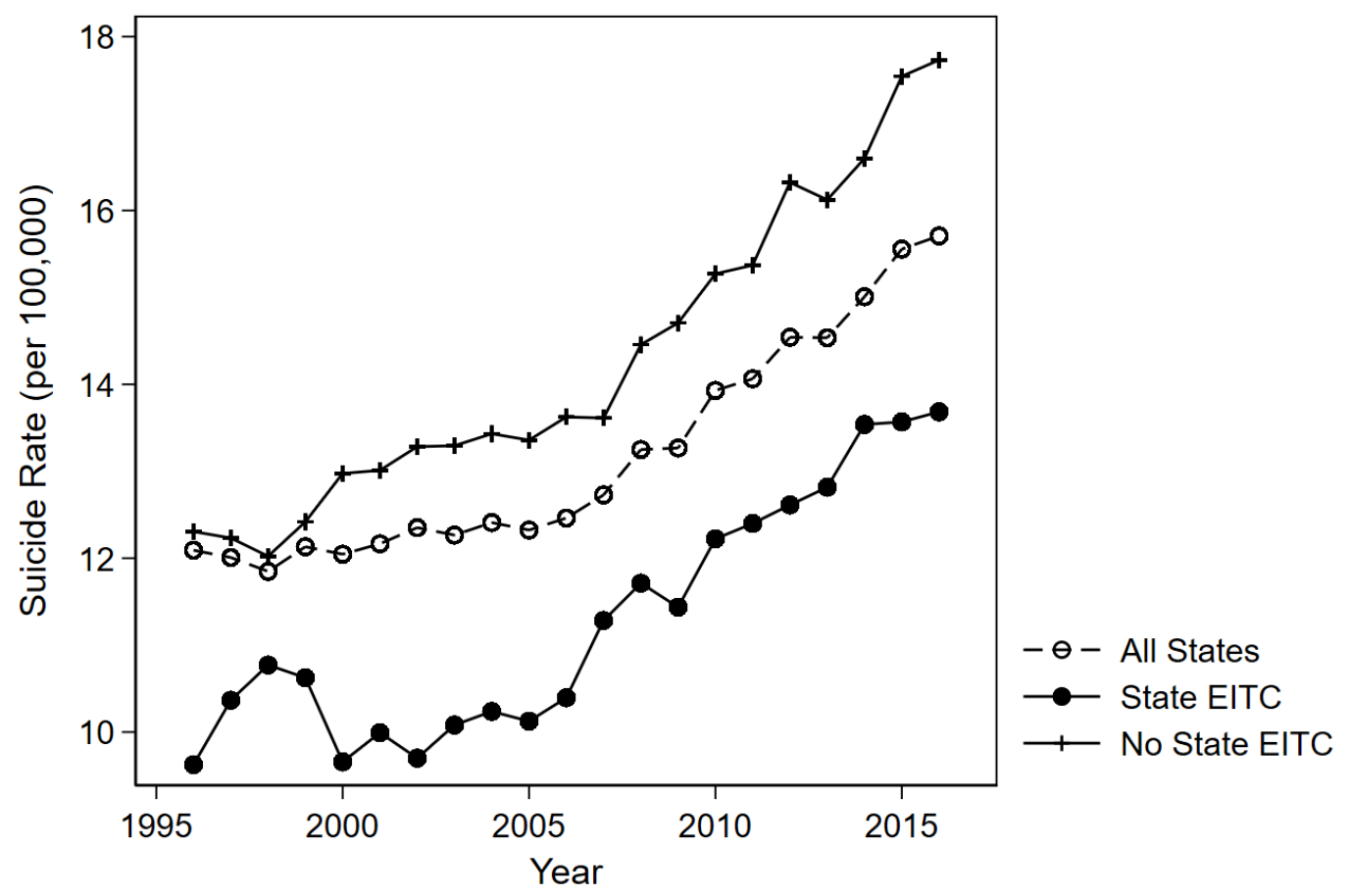


Table 1: Overview of State EITC Changes

Year

1997

1998

1999

2000

2001

2002

2003

2004

2005

2006

2007

2008

2009

2010

2011

2012

2013

2014

2015

2016

\# of State EITC Changes

\# of Switches across

Categories (No/Low/High) 
Table 2: EITC Benefit Amounts for 10\% Cutoff of Federal Credit

\begin{tabular}{llcl}
\hline \hline Year & 1 Child & 2 Children & 3+ Children \\
1996 & $\$ 215$ & $\$ 356$ & \\
1997 & $\$ 221$ & $\$ 366$ & $\$ 356$ \\
1998 & $\$ 227$ & $\$ 376$ & $\$ 376$ \\
1999 & $\$ 231$ & $\$ 382$ & $\$ 382$ \\
2000 & $\$ 235$ & $\$ 389$ & $\$ 389$ \\
2001 & $\$ 243$ & $\$ 401$ & $\$ 401$ \\
2002 & $\$ 251$ & $\$ 414$ & $\$ 414$ \\
2003 & $\$ 255$ & $\$ 420$ & $\$ 420$ \\
2004 & $\$ 260$ & $\$ 430$ & $\$ 430$ \\
2005 & $\$ 266$ & $\$ 440$ & $\$ 440$ \\
2006 & $\$ 275$ & $\$ 454$ & $\$ 454$ \\
2007 & $\$ 285$ & $\$ 472$ & $\$ 472$ \\
2008 & $\$ 292$ & $\$ 482$ & $\$ 482$ \\
2009 & $\$ 304$ & $\$ 503$ & $\$ 566$ \\
2010 & $\$ 305$ & $\$ 504$ & $\$ 567$ \\
2011 & $\$ 309$ & $\$ 511$ & $\$ 575$ \\
2012 & $\$ 317$ & $\$ 524$ & $\$ 589$ \\
2013 & $\$ 325$ & $\$ 537$ & $\$ 604$ \\
2014 & $\$ 331$ & $\$ 546$ & $\$ 614$ \\
2015 & $\$ 336$ & $\$ 555$ & $\$ 624$ \\
2016 & $\$ 327$ & $\$ 557$ & $\$ 627$ \\
Average all years & $\$ 276.67$ & $\$ 458.05$ & \\
& & & \\
\hline \hline
\end{tabular}




\section{Log (Suicides per 100,000)}

(1)

Panel A: Effects of EITC generosity (comparison group: no EITC)

Low EITC

$$
-0.0184
$$

High EITC

Panel B: Accounting for if EITC refundable (comparison group: no EITC)

$\begin{array}{lcc}\text { Low EITC no refund } & -0.0207 & -0.0229 \\ & (0.0242) & (0.0275) \\ \text { Low EITC with refund } & -0.0188 & -0.0215 \\ & (0.0148) & (0.0137) \\ \text { High EITC no refund } & -0.0291^{* *} & -0.0295^{* *} \\ \text { High EITC with refund } & (0.0133) & (0.0145) \\ & -0.0446^{* *} & -0.0427^{*} \\ & (0.0217) & (0.0224)\end{array}$

Panel C: Effects of EITC size

State-level EITC

$$
\begin{array}{cc}
-0.0397 * * & -0.0389 * * \\
(0.0168) & (0.0157)
\end{array}
$$

Panel D: Effects of introducing state-level

$$
\text { EITC }
$$

State-level EITC in place

$$
\begin{array}{cc}
-0.0309 * * & -0.0312 * * \\
(0.0137) & (0.0142)
\end{array}
$$

Year fixed effects

State fixed effects

$\mathrm{X}$

$\mathrm{x}$

$\mathrm{X}$

$\mathrm{X}$

$\mathrm{x}$

State-level controls

Observations

Robust standard errors, clustered by state, are shown in parentheses. State-level controls include annual state unemployment rates, annual state real GDP, and the share of the state population under 65 without any insurance coverage. ${ }^{*} p<0.10,{ }^{* *} p<0.05,{ }^{* * *} p<0.01$. 